\title{
Arv och äktenskap
}

Med början på 1950-talet ökade statens intresse för jordbrukets ägandeförhållanden i allmänhet och för samägande i synnerhet. I takt med att strukturrationaliseringen tog fart visade sig samägda jordbruksfastigheter utgöra en betydande andel av landets brukningsenheter och ägandeformen betraktades i allt större utsträckning som ett problem. De rättsliga förutsättningarna för samägande hade dock ändrats redan runt sekelskiftet 1900, och det var vid den tiden som syskonjordbruk tycks ha blivit vanligare. I detta kapitel riktar jag ljuset mot hur generationsskiftet på gårdarna gick till under 1900-talets första hälft.

I tidigare forskning om arvspraktik skiljs ofta mellan två huvudalternativ. Realarv, eller delbart arv, innebar att alla arvingar fick del av gården, som också i praktiken delades mellan dem. Motsvarigheten var ett enarvingesystem, där gården odelad överfördes till ett barn som på olika sätt åtog sig att kompensera sina syskon. Alternativen bottnar i två motstridiga principer: att hålla egendomen intakt och att trygga samtliga arvingars försörjning. ${ }^{260}$ En linje inom forskningen har gått ut på att försöka finna geografiska mönster i alternativens utbredning, vilket inte har varit någon enkel uppgift. Arvsförhållandena har varierat även inom mindre områden och allmänna slutsatser om olika arvssystems utbredning och funktion har varit svåra att dra. ${ }^{261}$ Ett antal lokalstudier om 1700- och 1800-talen har dock visat att det generella mönstret i Sverige var att gården odelad överfördes till ett barn. Delades en egendom upp berodde det vanligen på att den var stor. Studierna av arvsförhållanden under 1900-talet är ännu få. ${ }^{262}$ En närmare granskning av arvspraxis under 1900-talets första hälft framstår därför som välbehövlig, men istället för studier av ett 
mindre område har jag utgått från tre nationella enkäter om arvssedvänjor.

\section{Nils Wohlin och bondesamhällets förändring}

Tiden runt sekelskiftet 1900 präglades Sverige av en mycket snabb omvandling från jordbrukarnation till industrisamhälle. Den mest brännande politiska frågan var dock emigrationen. Från mitten av 1800-talet fram till 1910 utvandrade uppemot en miljon människor till Amerika. Utflyttningen var särskilt stor mot 1800-talets slut, och den blev vid den tiden en nationell ödesfråga. ${ }^{263}$ Emigrationens bakomliggande orsaker var dock i stor utsträckning okända, och för att bättra på kunskapsläget tillsatte riksdagen 1907 Emigrationsutredningen under ledning av statistikprofessorn Gustav Sundbärg. Utredningen arbetade i sex år och hann under denna tid publicera en mängd uppgifter om sociala och ekonomiska förhållanden i Sverige, både rörande sekelskiftet 1900 och föregående sekler. I slutbetänkandet hävdade Sundbärg att det var jordbrukets oförmåga att hålla jämna steg med befolkningsutvecklingen som utgjorde emigrationens grundorsak. ${ }^{264}$

Att intresset inriktades mot jordbrukets villkor medförde att en stor del av de insamlade uppgifterna avsåg landsbygdens förhållanden. I ett stort antal bilagor presenterades sociala och ekonomiska data om befolkningsutveckling, jorddelningens politik och praktik, näringsstatistik och produktionsutveckling. Utredarna intresserade sig även för hur bönders generationsskiften genomfördes, och en undersökning om det genomfördes av utredningens dåvarande sekreterare Nils Wohlin och publicerades 1910 som utredningsbilaga 10 under den något omständliga titeln Faran af bondeklassens undergräfvande i sammanhang med de gamla arfvejordåskådningarnas upplösning, emigrationen och bondejordens mobilisering. Wohlin drev tesen att bondebefolkningen under påverkan av ett tilltagande marknadstänkande hade övergett traditionella principer om vikten att bevara gården inom släkten och sätta familjens betydelse före individuella hänsyn. Istället för att betraktas som bondens dyrbaraste ägodel hade jord allt mer börjat betraktas som lös egendom, 


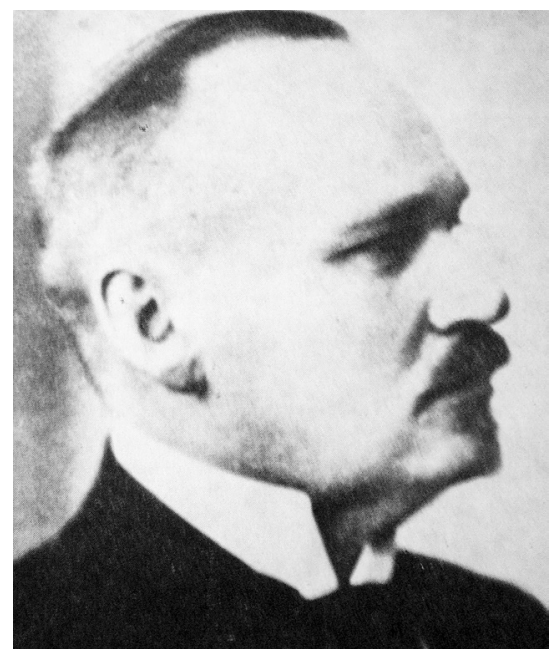

Nils Wohlin (1881-1948) var en säregen blandning av ekonom, statistiker och politiker. Han disputerade på en över 800 sidor lång avhandling om den svenska jordstyckningspolitikens historia och blev så småningom professor i statistik vid Stockholms högskola. Hans politiska gärning sträckte sig över flera decennier och han bytte upprepade gånger partitillhörighet mellan Bondeförbundet och Allmänna valmansförbundet. Karriären kröntes med två ministerposter i högerregeringar under 1920- och 1930-talet och avslutades med en lång tid på posten som chef för Tullverket. Foto: okänd.

en handelsvara som snabbt kunde gå från hand till hand. Wohlin baserade sina slutsatser på flera källor, men huvudmaterialet bestod av en enkätundersökning ställd till landets häradshvdingar. ${ }^{265}$

Wohlin beskrev både förutvarande och samtida arvspraxis och hans skildring har varit en given utgångspunkt för senare forskning. Denna har emellertid i huvudsak förhållit sig kritisk till hans framställning. Wohlin framställer 1800 -talets bönder i ett romantiskt skimmer och hans beskrivning har inte visat sig överensstämma med detaljerade studier av generationsskiften i bondesamhället. ${ }^{266}$ Analysen av enkätmaterialet präglades också av Wohlins förutbestämda synsätt. ${ }^{267}$ Även om slutsatserna alltså är av tvivelaktigt värde är enkätmaterialet ännu bevarat och möjligt att studera.

Wohlins intresse för bönders arvsförhållanden tog emellertid inte slut 1910. År 1918 utsågs han, då som riksdagsman för Bonde- 
förbundet, till ledamot i den statliga Jordkommissionen som var verksam mellan 1918 och 1923. Kommissionen tillsattes ursprungligen för att i Norrlandslagstiftningens efterföljd utreda bolagsförvärv av jord i södra och mellersta Sverige. Allt eftersom växte uppdragen till att innefatta flera centrala jordpolitiska frågor. ${ }^{268}$ Internt präglades kommittén av starka ideologiska motsättningar, kanske främst mellan den konservative Wohlin och den utpräglat liberale, stundtals radikale, Carl Lindhagen. Trots ideliga konflikter, om vilka inte minst otaliga reservationer till kommissionens förslag bär vittnesbörd, framarbetades radikala reformförslag inom så blandade ämnen som arrendelagstiftning, avveckling av fideikommiss, expropriationslagstiftning och bildandet av nya jordbruk. ${ }^{269}$ Därutöver genomförde kommissionen ett flertal statistiska undersökningar och enkäter. En av dem rörde samma fråga som upptagit Wohlins intresse i Emigrationsutredningen: praxis vid generationsväxlingar inom bondeklassen. Även om frågeformuläret denna gång var betydligt mer omfattande bär utformningen så tydliga spår av Emigrationsutredningens enkät att det är troligt att Wohlin hade direkt inflytande över den. Enkäten genomfördes 1919, men resultaten lades inte till grund för några konkreta förslag.

Drygt femton år senare fick Wohlin möjlighet att en tredje gång återkomma till arvsfrågorna då han 1935 utnämndes till ordförande för en statlig utredning med uppgift att bringa klarhet i hur överdriven skuldsättning inom jordbruket kunde förhindras. Inom ramen för arbetet konstruerades en enkät som till både utformning och omfång uppenbart var baserad på Jordkommissionens dito. I sitt slutbetänkande argumenterade 1935 års utredare, förutom Wohlin även hovrättsrådet Einar Anderberg och Lantbruksakademiens sekreterare Thure Björkman, för ett reformerat arvssystem efter tysk och norsk förebild. Det skulle enbart gälla bondgårdar och grundtanken var att den övertagande arvingen skulle erhålla en viss privilegierad ställning framför övriga arvingar. ${ }^{270}$ Förslaget förpassades dock tämligen omgående till papperskorgen och enkätens resultat återgavs bara kortfattat i en bilaga till utredningen. ${ }^{271}$ 
Genom olika utredningsuppdrag medverkade Nils Wohlin således vid utarbetandet av tre nationella enkäter om bönders arvssedvänjor. Så gott som samtliga inkomna enkätsvar - ett stort antal beskrivningar av arvsförhållanden i olika delar av landet under en period om nästan trettio år - finns ännu bevarade. I detta kapitel är det dessa uppgifter som står i fokus. Om en förändring i riktning mot mer samägande verkligen ägde rum under 1900-talets första hälft så bör den ha gett avtryck i enkätsvaren. Enkäterna kan också belysa arvsförhållanden i bredare bemärkelse, bland annat föräldrarnas roll i generationsskiftet och hur arvsfrågans lösning hängde samman med äktenskap och familjebildning.

\section{Enkätmaterialets möjligheter och brister}

Samtliga enkäter ställdes till landets domsagor, det vill säga en sammanhängande domkrets under ledning av en häradshövding. ${ }^{272}$ En domsaga kunde bestå av ett eller flera tingslag med var sin tillhörande häradsrätt där häradshövdingen fungerade som ordförande. ${ }^{273}$ Att enkäten ställdes till häradshövdingarna framstår således som rimligt; det var vanligen i häradsrätterna som lagfartsärenden, bouppteckningar och arvskiften hanterades. På de tre enkäterna inkom totalt 327 svar, varav 325 finns bevarade. ${ }^{274}$ Vad är det för typ av material, vilka uppgifter kan det ge och hur bör informationen bedömas?

Som framgår av tabell 3.1 på nästa sida var svarsfrekvensen mycket god för 1907 och 1935 års enkäter, men 1919 saknas svar från mer än var fjärde domsaga. Bortfallet är visserligen inte systematiskt de uteblivna svaren är jämnt fördelade över landet - men gör det svårt att följa utvecklingen på domsagenivå. Dessutom genomgick indelningen i domsagor relativt stora förändringar under perioden. Enbart i 69 fall, knappt 60 procent, finns bevarade enkätsvar från samma område vid alla de tre tillfällena. Möjligheten att studera förändringar på domsagenivå är med andra ord begränsad.

Jämförelser försvåras ytterligare av stora skillnader i uppgifternas omfattning. I enkäterna efterfrågades det inom domsagan gängse tillvägagångssättet vid jordens övergång till en ny generation. Detta 
Tabell 3.1. Inkomna svar på enkäter om arvssedvänjor 1907, 1919 och 1935 .

$\begin{array}{lccc} & 1907 & 1919 & 1935 \\ \text { Antal domsagor } & 121 & 125 & 117 \\ \text { Antal svar } & 115 & 96 & 116 \\ \text { Svarsfrekvens (procent) } & 95 & 77 & 99\end{array}$

Källa: Enkätsvar rörande arvssedvänjor; Emigrationsutredningen (1907), Jordkommissionen (1919) samt Utredningen om jordbrukets skuldförhållanden (1935), RA. Antalet domsagor är hämtat ur Statskalendern för respektive år.

delades upp i ett antal delfrågor: 5 frågor 1907 och 16 respektive 15 i de två senare enkäterna. En del svar är mycket detaljerade, andra desto knapphändigare. Häradshövdingen, som vanligen står som uppgiftslämnare, tycks främst ha utgått från egna erfarenheter, men ibland framgår att uppgifterna tagits fram i samråd med häradsrättens medlemmar eller att enskilda nämndemän och länsmän tillfrågats. I några fall gjordes direkta undersökningar av arvskiften, lagfartsansökningar och inteckningar. Å andra sidan angavs i flera enkätsvar att en del av de efterfrågade uppgifterna inte kunde lämnas och ibland låg utanför häradshövdingens verksamhet och erfarenhet. Svaren ger alltså ingen fullödig bild av arvspraxis och på grund av svarens knapphet är det ibland svårt att jämföra olika svar. Till det kommer svårigheten att bedöma olika kvantitativa omdömen, exempelvis vari skillnaden ligger mellan "vanlig", "förekommande" och "inte så sällan".

Sammantaget är således enkätsvaren förbundna med problem både vad gäller representativitet och jämförbarhet. Trots dessa brister menar jag att materialet kan ge viktig information. Enkätsvaren lämpar sig inte för att fastställa exakta arvsförhållanden inom varje domsaga, men om analysen begränsas till mer övergripande nivåer behöver inte problemet vara så stort. Jag är i första hand inte ute efter praxis vid varje nedslagsår utan efter förändringar mellan de tre enkäterna. En del enkätfrågor var synnerligen detaljerade - exempelvis huruvida odlingsjord på utmarkerna vanligen undantogs som förtida arv och hur reverser vid inlösen hanterades - och att sådana uppgifter inte alltid kunde lämnas är inte särskilt konstigt. På de mer centrala frågorna om 
exempelvis hur gården fördelades mellan arvingarna håller svaren en mer tillfredsställande nivå.

I det följande behandlar jag särskilt tre problem: Vad blev generationsväxlingens resultat, stannade utlösta syskon kvar på gården och hur gick det till när föräldragenerationen lämnade över ansvaret? De enkätfrågor som rör dessa ställdes på i det närmaste samma sätt i de tre enkäterna och kunde i allmänhet besvaras. ${ }^{275}$ Om inga förändringar inträffade över tid borde således svaren vara ungefär desamma.

\section{Arv på olika sätt}

Huvudfrågan i samtliga enkäter rörde generationsskiftets slutresultat. För att konkretisera frågan beskrevs i frågeformulären olika möjliga utfall. ${ }^{276}$ Alternativet att gården "klyvs [...] mellan arvingarna” betecknades i enkätsvaren genomgående som mycket sällsynt. Det var enbart i några enstaka områden som det var vanligt, däribland Bohusläns kustlandskap, delar av Norrbotten samt övre Dalarna. ${ }^{277}$ Betydligt vanligare var att hemmanet "övertas [...] okluvet av en arvinge"; det var regel i stora delar av landet. Dessa två alternativ kan sägas motsvara de två arvsprinciper som diskuterats i arvsforskningen: delbart respektive odelbart arv. I enkäterna kompletterades dock dessa möjligheter med ett tredje svarsalternativ: att gården fortsatt brukades av arvingarna "en längre tid framåt eller allt fortfarande okluvet men för gemensam räkning". Att detta alternativ över huvud taget förekom är intressant i sig eftersom det antyder en medvetenhet om att generationsväxlingen inte alltid utföll i enlighet med klassiska principer om delbart och odelbart arv.

Fastigheter som brukas gemensamt av arvingar kan utgöra en beskrivning av syskonjordbruk, men behöver inte vara det; i flera enkätsvar framgår att det var en vanlig lösning när det bland arvingarna fanns omyndiga barn. Det gemensamma brukandet av gården var i sådana fall snarast en följd av att en förälder gått bort innan barnen hunnit växa upp. Det var en relativt vanlig lösning på svensk landsbygd till och med 1800-talet, men den avslutades när 
Diagram 3.1. Förekomst av långvarigt gemensamhetsbruk mellan arvingar 1907, 1919 och 1935.

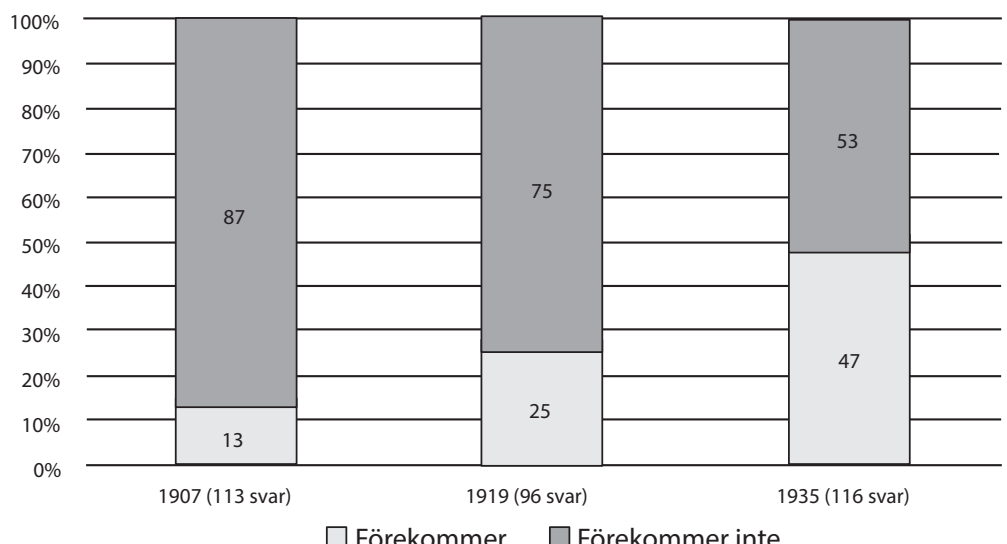

Källa: Se källangivelser under tabell 3.1. Anm: Gemensamhetsbruk mellan arvingarna har ansetts existera när enkätsvaren angivit att det "förekommer", är "vanligt" eller liknande, däremot inte när det sagts vara "sällsynt" eller "ovanligt".

barnen uppnått myndig ålder. ${ }^{278}$ I en del av enkätsvaren sades dock långvariga gemensamhetsbruk förekomma utan att det motiverades med omyndiga arvingar. Andelen svar av detta slag för respektive enkät återges i diagram 3.1.

Långvariga gemensamhetsbruk sades förekomma i 13 procent av svaren 1907. Andelen fördubblades i 1919 års enkät och därefter följde ytterligare en dubblering fram till 1935 då hälften av alla svar angav att det förekom. Det ska inte tolkas som att vartannat generationsskifte 1935 slutade med att arvingarna gemensamt drev vidare gården; även där långvariga gemensamhetsbruk förekom var det avgjort vanligast att en av arvingarna ensam tog över gården. Det finns dock vissa tecken som pekar på att gemensamhetsbruken ökade också i förhållande till andra alternativ. I sex av svaren 1935 sades gemensamhetsbruk vara det vanligaste utfallet vid generationsskiften och i ytterligare ett tiotal sades det vara ungefär lika vanligt som att en arvinge ensam tog över gården. ${ }^{279}$ Enkätsvaren ger därmed en tydlig fingervisning om att samägande mellan arvingar blev vanligare under 1900-talets första hälft. När 


\section{Frågeformulär}

rörande sedvănịor vid jordbruksiastigheters övergảng à ny generation m. m.

De jümlikt Kungl. Maj:ts hemyndigande den 23 maj 1935 tillkallade sakkunniga för utredning av frâgan om atgärder till reglering av jordbrukets skuldförhallanden skola enligt de för de salkkunnigas arbete givna direktiven b. a. undersöka spörsmålet om vidtagande av âtgärder till förehyrramile ar en för jordbruksdriftens upprätthallande under vëxlande konjunkturer alltför betungande skuldsättning i samband med arvskifte av jordbruksfastighet eller sădan fastighets överlatande i nnnan ordning pă ny generation. För verkställandet av sistnämnda undersïkning î det erforderligt att erhâlla kännedom om nuvarande sedvänjor vid jordbraksfastigheters övergang â ny generation. I sidant syfte hava de sakkunniga utarbetat förevarande frâgeformulïr, som torde besvaras med största möjliga noggrannhet och utförlighet och senast före irets utging med posten atersïndas under adress Assessor R. Dahlgren, Riksdagshuset, Stockholm.

Stockholm i norember 1935

NILS WOHLIN.

THURE RJORKMAN.

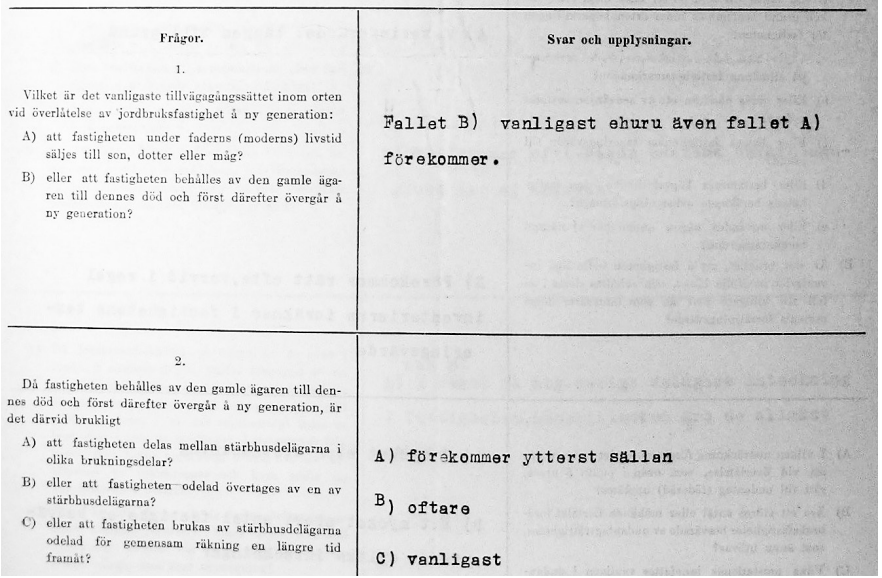

Första sidan i 1935 års enkät, med svar från Linde domsaga i Västmanland. Fastigheter sägs ytterst sällan delas mellan arvingarna, oftare övertas odelade av en delägare men vanligast var att de brukades gemensamt av arvingarna. Foto: författaren.

Jordbrukets utredningsinstitut på 1950-talet uppmärksammade samägandets omfattning hade det följaktligen vuxit i styrka under flera decennier. ${ }^{280}$

Hur såg då detta samägande ut i praktiken? Vad avsågs med att arvingar drev vidare gården för gemensam räkning? Uppgifterna i enkätsvaren är ofta knapphändiga och gör det svårt att med säkerhet säga vilka företeelser uppgiftslämnarna avsåg. I en del fall finns dock kommentarer och upplysningar som belyser och konkretiserar sakförhållanden, och av dem framgår att gemensamhetsbruk 
ofta innebar att flera arvingar bodde ihop och tillsammans drev föräldragården, ibland under mycket lång tid - rentav livet ut. En häradshövding i södra Småland svarade att "de fall är talrika då hemmanet efter båda föräldrarnas död brukas av stärbhusdelägarna för gemensam räkning". ${ }^{281}$ I ett svar från Ångermanland framkom liknande uppgifter, med tillägget att förhållandena inte sällan bestod "för avsevärd tid". ${ }^{282}$ I Fryksdal i Värmland förekom det "ej så sällan att syskon, även bröder, om de är ogifta, behålla hemmanet utan skifte och bruka det samfällt under sin livstid". 283 Det var dock inte alltid så att samtliga arvingar stannade kvar. I Gudhems härad på Västgötaslätten sades gemensamhetsbruk främst förekomma när en av föräldrarna ännu var i livet, men det tillades att gården därefter övertogs av en arvinge eller "av några arvingar gemensamt". 284

Två förutsättningar tycks ofta ha samvarierat med gemensamhetsbruk. Den ena var syskonens civilstånd. I ett enkätsvar från Skaraborg sades exempelvis syskonen behålla gården oskiftad "särskilt om ogifta systrar finnas i hemmet" och i ett svar rörande Älvsborgs län "då syskonen är äldre och ogifta". ${ }^{285}$ I östgötska Finspångalän sades det vara vanligast att en arvinge ensam övertog gården, men "om ingen av dödsbodelägarna är gift, inträffar ibland att fastigheten brukas gemensamt". ${ }^{286}$ Den andra var de ekonomiska förutsättningarna. "Där två eller flera syskon överta fastigheten är det mest av ekonomiska skäl och för att bereda flera arbete och utkomst", rapporterades från Västmanland. ${ }^{287}$ Ett fattigt bo kunde enligt en annan uppgiftslämnare "omöjliggöra försäljning och tvinga dödsbodelägarna att för att bevara åt sig några utkomstmöjligheter behålla fastigheten och leva i oskift[at] bo".288 Men i ett svar från Småland framhölls tvärtom att det "blott i väl burgna hem" förekom att gården drevs vidare av arvingarna gemensamt. ${ }^{289}$ Det kom rentav motstridiga svar från ett och samma landskap: i södra Uppland förekom gemensamhetsbruk endast i de gynnsamma fall där "dödsboets ekonomi det tillåter", i landskapets norra del när "stärbhusdelägarna är hemmavarande och ogifta samt boets ekonomiska ställning är mindre gynnsam". ${ }^{290}$

Förhållandena kunde med andra ord variera även inom mindre 
områden och det är därför problematiskt att jämföra olika län eller landskap. ${ }^{291}$ Över större områden går det dock att göra en grov jämförelse. I en annan av Emigrationsutredningens bilagor lanserade den nämnde Gustav Sundbärg en indelning av Sverige i tre demografiska huvudområden baserat på graden av inomäktenskaplig fruktsamhet: öst (låg fruktsamhet), väst (hög fruktsamhet) och norr (mycket hög fruktsamhet). ${ }^{292}$ Denna indelning har anammats av senare forskare, som har adderat kulturella och socioekonomiska skillnader till Sundbärgs demografiska indelning samt visat att gränserna ägde bestånd långt fram i tiden. ${ }^{293}$ Det kan därför finnas skäl att granska hur förekomsten av gemensamhetsbruk fördelar sig regionalt. I tabell 3.2 har jag brutit upp enkätsvarens uppgifter på fyra regioner. ${ }^{294}$

Tabell 3.2. Regional förekomst av långvariga gemensamhetsbruk 1907, 1919 och 1935.

\begin{tabular}{lcccccc} 
& & \multicolumn{2}{c}{$\mathbf{1 9 0 7 9}$} & & \multicolumn{1}{c}{1935} \\
& Antal & Andel & Antal & Andel & Antal & Andel \\
Väst & 14 & 33 & 11 & 31 & 24 & 55 \\
Öst & 0 & 0 & 5 & 19 & 13 & 42 \\
Syd & 0 & 0 & 3 & 23 & 9 & 53 \\
Norr & 1 & 3 & 5 & 28 & 9 & 35 \\
Totalt & $\mathbf{1 5}$ & $\mathbf{1 3}$ & $\mathbf{2 4}$ & $\mathbf{2 5}$ & $\mathbf{5 5}$ & $\mathbf{4 7}$
\end{tabular}

Källa: Se källangivelser under tabell 3.1. Anm: Väst = Halland, Småland, Västergötland, Bohuslän, Dalsland och Värmland; Syd = Skåne och Blekinge; Öst = Östergötland, Gotland, Örebro, Södermanland, Västmanland, Uppland, Stockholm och Gävleborg; Norr = Kopparberg, Jämtland, Västernorrland, Västerbotten och Norrbotten.

Sammanställningen bygger på svårbedömda utsagor och måste tolkas därefter, men i viss utsträckning tycks Västsverige märka ut sig med högst andel gemensamhetsbruk vid alla tre enkäterna. Åren 1919 och 1935 var skillnaden mindre, men 1907 var den markant. Av de femton svar som då angav att gemensamhetsbruk mellan arvingar förekom härrörde alla utom ett från västra Sverige. Vad kan det ha berott på att samägande i början av 1900-talet var så mycket vanligare i västra Sverige? Christer Winberg har i flera arbeten visat att det fanns betydande skillnader mellan Västsverige och Östsverige på ett antal olika punkter, bland annat ifråga om 
äktenskaplig fruktsamhet, politiskt röstningsmönster och arbetstid inom jordbruket. ${ }^{295}$ Han understryker att den gemensamma nämnaren för det som utmärkte Västsverige var att "familjen står i centrum, dess oberoende och egendomen som basen för dess existens". ${ }^{296}$ Det går inte att komma ifrån att denna karaktäristik passar väl in på arvingar som gemensamt brukar sin föräldragård. Samtidigt rör det sig sannolikt inte om någon urgammal kulturgräns för samägande och den västsvenska särarten ska heller inte överdrivas. Siffrorna i tabell 3.2 visar tydligt att gemensamhetsbruk inte var en uteslutande västsvensk företeelse. Vid den sista enkäten inkom uppgifter om gemensamhetsbruk från alla län utom Jämtland och Södermanland. ${ }^{297}$

Summeras de hittills vunna resultaten framskymtar en gradvis etablering av ett flerarvingesystem under 1900-talets första decennier. Det går inte att med säkerhet fastställa hushållsstrukturen på det ökande antalet enheter där flera arvingar gemensamt övertog fastigheten, men de beskrivningar som finns ligger väl i linje med de samägande syskonenheter som Jordbrukets utredningsinstitut uppmärksammade på 1950-talet. Att allt fler generationsskiften slutade i gemensamhetsbruk innebär emellertid inte att de fick en dominerande ställning - det vanligaste var att en arvinge ensam övertog gården. En viktig fråga är vad som hände med de utlösta syskonen på sådana enheter.

\section{Samboende på skilda villkor}

I Bondeklassens undergrävande menar Nils Wohlin att omsorgen om familjens medlemmar i äldre tid var ett grundläggande drag i bönders mentalitet. Eftersom vanligen bara en arvinge kunde överta gården var det regel att utlösta arvingar under avsevärd tid stannade kvar på gården och hjälpte den nye ägaren med gårdens skötsel. ${ }^{298}$ Wohlins idealbild av ett äldre sammanhållet hemmansägarhem var säkerligen anledning till att alla tre enkäter innehöll frågan om utlösta syskon stannade på gården en längre tid efter arvskiftet och om föräldrahemmet utgjorde en tillflyktsplats för dem även framöver. ${ }^{299}$ Svaren innehöll inte något entydigt ja, vilket Wohlin 
bittert tolkade som att "de krassa och egoistiska beräkningarna" trätt i förgrunden. ${ }^{300}$ Omständigheterna varierade emellertid med syskonens förutsättningar. Inez Egerbladh visar i sin undersökning av ett par norrländska socknar att syskon som var inneboende hos gårdsägaren ofta led av fysiska eller mentala handikapp. ${ }^{301}$ Att sjukliga syskon ofta erhöll rätt att bo kvar hos den nye ägaren framträder tydligt i enkätsvaren, särskilt i början av 1900-talet. Sådana förhållanden nämns i merparten av enkätsvaren 1907, men förefaller sedan ha blivit mer sällsynta och nämns bara sporadiskt 1935. I dessa fall tillämpades ett slags undantagskontrakt: i utbyte mot arvslotten fick sjukliga syskon "fri bostad, föda, kläder och vård, mot skyldighet, att efter förmåga biträda hemmansägaren i arbete vid hemmanet". ${ }^{302}$ Praxis och betydelse kan givetvis ha varierat beroende på förutsättningar i det enskilda fallet. I en del fall var det säkert till stor nytta för den nytillträdde ägaren att ha en vuxen arbetare i hushållet. Andra gånger rörde det sig sannolikt mer om omvårdnad än något egentligt tillskott av arbetskraft.

Att den sjukes arvslott fick innestå eller helt överläts till det syskon som övertagit gården kunde ha stor betydelse, men berodde givetvis på familjeförhållandena. Var syskonen få omfattade varje arvslott en stor del av egendomen, men skulle hemmet delas på tio barn eller fler var de mindre. Att sjukliga syskon fick bo kvar på gården hade sannolikt ekonomiska skäl i vissa fall, i andra stod troligen samhörighetskänslor i förgrunden. För kroppsligt eller mentalt försvagade personer var alternativen inte så många. Om de inte blev kvar i föräldrahemmet fick de, som en häradshövding drastiskt formulerade det, "lämnas åt sitt öde" - antingen ligga kommunen till last eller sändas till någon vårdinrättning. ${ }^{303} \mathrm{Med}$ tiden blev det senare allt vanligare, och att hemmavarande sjukliga syskon omnämndes allt mer sällan var sannolikt en effekt av den offentliga vårdens kraftiga utbyggnad under 1900-talets första decennier. Enbart mellan 1900 och 1950 femdubblades antalet omhändertagna vid olika typer av vårdinstitutioner. ${ }^{304}$ Sjukliga vuxna omhändertogs i allt mindre utsträckning inom familjen utan blev med tiden ett samhälleligt ansvarsområde.

Hemmavarande sjukliga syskon var ett specialfall, men hur 
var praxis för friska och arbetsdugliga syskon som inte fătt överta gården? Baserat på enkätsvaren går det att dra tre slutsatser. För det första var det ingen okänd företeelse att inlösta syskon stannade kvar hos den nye ägaren, och mycket tyder på att det blev vanligare med tiden. Uppgifter om sådana förhållanden finns i ett drygt tjugotal enkätsvar både 1907 och 1919, även om antalet är något osäkert då det i en del svar inte görs någon skillnad gentemot praxis för sjukliga syskon. I materialet från 1935 finns uppgifter om kvarboende syskon i nästan vartannat svar, och gäller sällan sjuka eller handikappade personer.

För det andra var handlingsmönstren tydligt könsberoende. Att vuxna bröder stannade kvar nämns bara i något enstaka svar 1907 och 1919. ${ }^{305}$ De lämnade hemmet tämligen omgående och sökte arbete på annat håll. Ett motiv sades vara de förändrade maktförhållandena inom familjen: "de gå ej gärna som tjänare under sin bror", skrev en uppgiftslämnare i Skåne. ${ }^{306}$ År 1935 märks dock en viss ökning av antalet kvarboende bröder, ibland med tillägget att de var avlönade av den nye ägaren. ${ }^{307}$ För systrar var situationen en annan. Det framgår redan i utformningen av enkätens frågor. I de två första enkäterna klumpades ogifta systrar ihop med sjukliga eller svagsinta syskon, vilket stundtals gör det svårt att urskilja utlösta systrars handlingsmönster. Generellt tycks dock även de ha lämnat gården för att söka plats på annat håll, inte sällan i närliggande städer eller industrisamhällen, emigrerat eller flyttat i samband med giftermål. ${ }^{308}$ I vissa fall hade dock "oförsörjda systrar" en position liknande de sjukliga syskonens, det vill säga att de bodde kvar mot att arvslotten innestått hos den nye ägaren. ${ }^{309}$

För en del systrar framgår emellertid ytterligare ett handlingsalternativ. I ett svar från Skåne 1907 meddelades att om den nye hemmansägaren - som förutsattes vara man - var "ogift och har någon ogift syster, systern brukar stanna kvar och sköta hushållet”. ${ }^{310}$ Liknande förhållanden förekom i Västerbotten och Jämtland, men också i Skaraborg, där det sades vara relativt vanligt att "ogifta systrar stanna hos en ogift broder tills han ingår äktenskap". ${ }^{311}$ Att en ogift syster kunde sköta broderns hushåll nämns uttryckligen i sju svar 1907 och blev vanligare med tiden. ${ }^{312}$ Att kvarboende 
syskon nämndes i nästan vartannat svar 1935 berodde i själva verket främst på att ogifta systrar stannade kvar i hemmet. Uppgifterna kommer från olika håll i landet och mönstret går att finna såväl i slättbygder som Skåne och Västergötland som i norra Sveriges skogslän. Att en syster övertog gården och använde kvarboende bröder som arbetskraft i jordbruket nämns inte i ett enda enkätsvar och var sannolikt mer eller mindre otänkbart. Även om alla arvingar formellt hade lika stor rätt till jorden, fanns (och finns) ett tydligt ideal att jordägaren var en man.

För det tredje berodde praxis på syskonens civilstånd. I ett svar från Skåne 1935 tydliggjordes förutsättningarna: var övertagaren en gift son flyttade syskonen omgående, men var han ogift "är det däremot vanl[igt] att en ogift syster stannar hos honom". ${ }^{313}$ Det gällde lika mycket i andra riktningen och det var i huvudsak ogifta systrar som stannade kvar, inte sällan med tillägget "tills de gifta sig". ${ }^{14}$ I södra Uppland förekom det att en inlöst bror arbetade kvar på gården, med tillägget att han "i dylika fall alltid är ogift". ${ }^{315} \mathrm{Om}$ antingen övertagaren eller systern sedan gifte sig flyttade systern från gården. Att gifta syskon bodde kvar förekom nästan inte alls. ${ }^{316}$

Jämförs uppgifterna om kvarboende syskon med det tidigare redovisade mönstret för gemensamhetsbruk framträder flera likheter. Ingen av företeelserna var knuten till någon särskild landsända, båda tycks över tid ha ökat i omfattning och de kännetecknades inte sällan av att de inblandade var ogifta. Den som inte var fullt insatt $\mathrm{i}$ ägandeförhållandena märkte förmodligen ingen större skillnad mellan samägda enheter med flera kvarboende delägare och gårdar där en arvinge formellt övertagit ägandet samtidigt som ogifta syskon fortsatte att utgöra en del av hushållet. Sammantaget förstärks därmed intrycket att syskonjordbruk var på frammarsch.

Den mest markerade ökningen tycks ha inträffat under 1920och 1930-talen, decennier som präglades av återkommande ekonomiska kriser. En bidragande orsak till att allt fler vuxna syskon bodde tillsammans på gårdarna kan således ha varit försämrade framtidsutsikter och arvingars svårigheter att få anställning i andra sektorer. I enstaka enkätsvar framkommer sådana faktorer. I ett 
svar från Kristianstads län 1935 påpekades att "under de svåra åren 1931-1933 inträffade det att ogifta utlöste stärbhusdelägare från städer och samhällen sökte sig tillbaka till det forna hemmet, där de dock stannade endast till dess möjlighet till arbete på annat håll erbjöds". ${ }^{317}$ Kristider kan ha förstärkt arvingarnas bundenhet till fädernetorvan och fungerat som ett slags skyddsnät, men syskonjordbruken var i tillväxt under hela perioden och kan inte uteslutande ses som en effekt av arbetsmarknadskriser. I enkätsvaren kunde de framstå som temporära lösningar i väntan på den naturliga fortsättningen: arvskifte och äktenskap. Hur ofta sådana förhoppningar infriades är emellertid osäkert. Att adjektivet ogift så ofta nämns i samband med syskonen antyder att äktenskapet har en nyckelroll. Det finns därför skäl att fördjupa diskussionen på denna punkt.

\section{Uteblivna äktenskap som problem}

I forskning om äktenskapsförhållanden har John Hajnals uppdelning i skilda mönster för västra och östra Europa varit en given utgångspunkt. ${ }^{318}$ Bland andra ekonomhistorikern Christer Lundh och historikerna Lennart Palm och Malin Lennartsson har undersökt svenska giftermålsmönster med tyngdpunkt i första hand på äktenskapsåldern under tidigmodern tid och diskuterat hur väl Sverige passade in i Hajnals västeuropeiska mönster. ${ }^{319}$ Mer sällan har det lyfts fram att hans karaktäristik av det västeuropeiska giftermålsmönstret utöver äktenskapsåldern även har en andra delkomponent: en hög andel vuxna ogifta. ${ }^{320}$ En av få svenska studier på detta tema är Sten Carlssons undersökning av ogifta kvinnor i Sverige fram till cirka 1860. Bland ståndspersoner (i huvudsak adeln och prästerskapet) finner Carlsson att en stor andel kvinnor - i mitten av 1800-talet mer än var tredje - förblev ogifta livet igenom. Numerärt utgjorde dock ståndspersoner en liten grupp och inom den betydligt större och i detta sammanhang mer intressanta bondebefolkningen var förhållandena annorlunda. Ännu vid 1800-talets mitt ingick mer än 90 procent av alla bonddöttrar förr eller senare äktenskap. ${ }^{321}$ Av den tiondel som förblev ogifta hade 
många fysiska eller mentala funktionsnedsättningar. Carlsson drar slutsatsen att den "friska och arbetsföra bonddottern" så gott som alltid blev gift. ${ }^{322}$

Den låga andelen ogifta innebär att Hajnals modell stämmer dåligt med 1700- och 1800-talets svenska bondesamhälle. Under 180o-talets lopp inträffade emellertid avgörande förändringar. Giftermålsfrekvensen sjönk stadigt under hela 1800-talet och nådde en bottennivå runt sekelskiftet 1900. ${ }^{323}$ Historikern Gunnar Qvist beräknar att under halvseklet 1870-1920 var nästan varannan kvinna mellan 20 och 40 år ogift. ${ }^{324}$ Det är uppseendeväckande, särskilt mot bakgrund av Carlssons bild av förhållandena några decennier tidigare. En anledning var att många inte gifte sig förrän de med marginal passerat 30 år, men många förblev också ogifta livet igenom. ${ }^{325}$ Vid sekelskiftet 1900 var närmare en fjärdedel av alla kvinnor, och ungefär var sjätte man, ännu ogifta vid 40 års ålder. ${ }^{326}$ Det är höga siffror, även i en europeisk kontext. Av Béla Tomkas sammanställning av europeisk statistik framgår att andelen ogifta personer i Sverige relativt sett var hög, framför allt för kvinnor. Sverige hade år 1900 den högsta andelen ogifta kvinnor i Europa och behöll sin tätposition under seklets första hälft. ${ }^{327}$

Kort sagt, under det sena 1800-talet och det tidiga 1900-talet uppkom en stor grupp ogifta vuxna som i många fall förblev ogifta. Det har ofta kopplats till den omfattande urbaniseringen under denna period. Gunnar Qvist har visat att redan under 1800-talets första hälft var andelen ogifta högre i städerna än på landsbygden, ett mönster som förstärktes när städerna växte. ${ }^{328} \mathrm{I}$ sin studie av familjebildning i Linköping och Sundsvall under 1900-talets första decennier bekräftar Hans Nilsson och Lars-Göran Tedebrand att de ogifta var fler i städerna än på landsbygden. De understryker att det var städerna som ledde utvecklingen mot ett västeuropeiskt giftermålsmönster. ${ }^{329}$ Med tiden utjämnades emellertid skillnaden mellan stad och landsbygd. Historikern Johannes Daun, som studerat fruktsamhet i den starkt växande staden Borås, visar att andelen ogifta vuxna uppgick till runt en tredjedel av befolkningen 1855 men successivt sjönk till en fjärdedel. När Daun jämför utvecklingen med en närliggande landsbygdssocken finner han 
det omvända: en ökande andel ogifta. Runt 1920 var skillnaderna mellan stad och landsbygd nära nog utjämnade. ${ }^{330}$

Den växande gruppen ogifta vuxna var således inte uteslutande ett urbant fenomen, däremot dröjde det några årtionden innan motsvarande ökning visade sig på landsbygden. Det var inte enbart de längst ner på den sociala skalan som förblev ogifta. Sofia Holmlund finner att det under 180o-talets lopp blev vanligare att söner som övertog gårdar inte gifte sig. Under 180o-talet var chanserna till äktenskap väsentligt större för arvingar som övertog gården, men mot seklets slut förändrades mönstret och under 1900-talets första decennier var det rentav vanligare med äktenskap bland dem som inte ärvde familjens jordegendom. ${ }^{331}$

Varför uteblev äktenskapen? För att finna en förklaring är det naturligt att först granska de demografiska förutsättningarna. Andra hälften av 1800-talet präglades av det systemskifte som ofta benämns den demografiska transitionen: höga födelse- och dödstal ersattes med låga. Trots sjunkande giftermålstal ökade antalet födda i Sverige mycket kraftigt under andra hälften av 1800-talet. Strax före 1850 föddes i medeltal cirka 100000 barn per år i Sverige, under seklets sista decennier drygt 130000 - en drygt trettioprocentig ökning på ett fåtal decennier upp till en nivå som inte matchades ens under efterkrigstidens rekordår och babyboom, då toppnoteringen låg på knappt 125000 födda per år. ${ }^{332}$ Samtidigt sjönk dödligheten, särskilt för barn. En allt större andel av en årskull nådde vuxen ålder.

En effekt av utvecklingen var att det i slutet av 1800-talet och början av 1900-talet fanns ovanligt många unga vuxna i Sverige. En stor andel av dem emigrerade, men trots det ökade befolkningen i åldern 15 till 39 år med en miljon mellan 1870 och $1930 .{ }^{333}$ Den demografiska utvecklingen ger en viktig pusselbit för att förstå de strukturella förutsättningarna, men duger inte mycket till för att förklara varför färre gifte sig. Med en stor grupp i giftasmogen ålder vore det snarast rimligt att vänta sig att giftermålsfrekvensen ökade, men den förblev låg fram till 1930-talet. En förklaring som förts fram är en demografisk skevhet mellan land och stad. Ännu 1870 bodde nästan 90 procent av Sveriges befolkning på landsbygden, men under de följande decennierna flyttade allt fler in till städer 


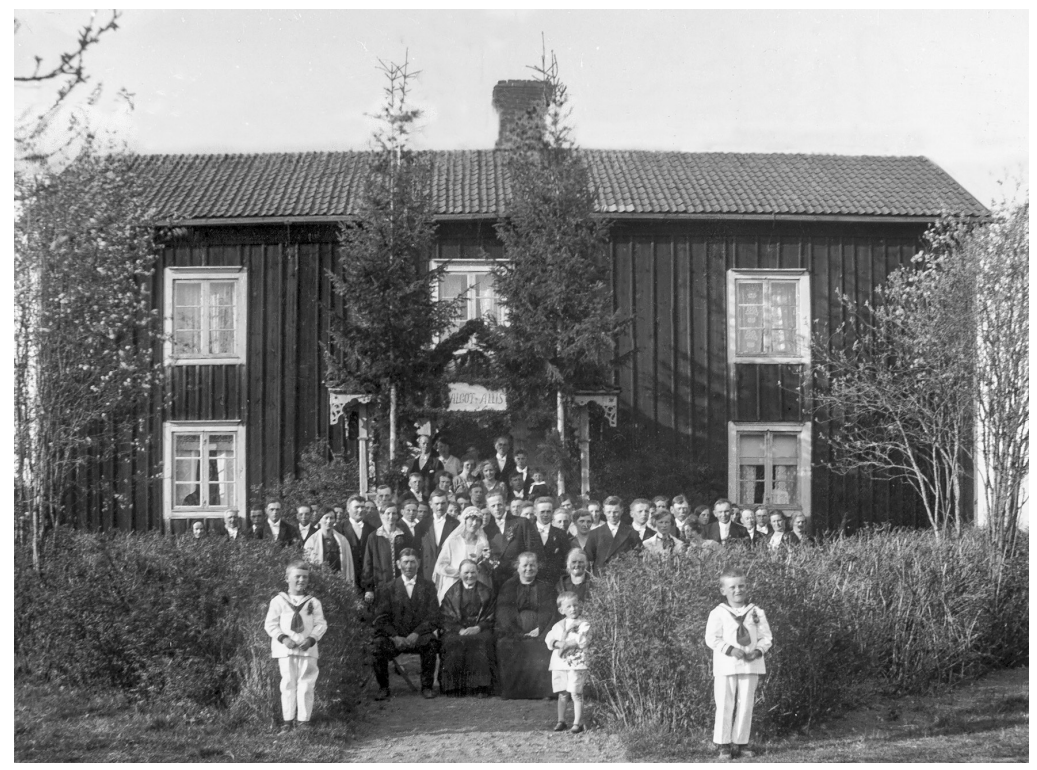

Arv och äktenskap var nära förknippade med varandra. Giftermål symboliserade starten på något nytt och ett hopp för gårdens framtid. Bröllop i Tuna socken, Småland, 1928. Foto: Kalmar läns museum.

och industriorter. ${ }^{334}$ Det var främst yngre personer som flyttade och efter hand blev det allt tydligare att det främst var kvinnor som lämnade landsbygden. ${ }^{335} \mathrm{På}$ 1930-talet uppmärksammade den statliga Befolkningskommissionen den sneda könsfördelningen och underströk att den fick allvarliga konsekvenser för äktenskapsbildningen på landsbygden eftersom det "för en ogift man, som önskar gifta sig, måste vara jämförelsevis svårt att på landsbygden finna en kontrahent inom åldersgrupperna 20-35 år" ${ }^{336}$

Kan demografisk skevhet förklara de få äktenskapen på landsbygden? Befolkningskommissionens siffror avser situationen 1935, då äktenskapsfrekvensen snarast var på väg att vända uppåt igen. Hur förhållandena sett ut tidigare är svårt att avgöra, då de folkräkningar som från 1800-talets slut genomfördes ungefär vart tionde år dessvärre inte ger tillräckliga uppgifter för att kunna beräkna andelen ogifta i olika åldrar. Det är dock tveksamt om det förelåg någon större skevhet i könsfördelningen, åtminstone före 
1900-talet; statistiska uppgifter från år 1900 visar att det i de flesta län fanns fler kvinnor än män på landsbygden. ${ }^{337}$ Enkätmaterialet visade också att det är svårt att extrapolera Befolkningskommissionens tes bakåt i tiden. Uppgifter om att ogifta systrar kunde bo kvar som delägare i sterbhus eller hos en likaledes ogift bror understryker att de ogifta kvinnorna inte lyste med sin frånvaro - den yngre ogifta kvinnan på landsbygden tycks inte alls ha varit ovanlig. I förbifarten gjorde faktiskt Befolkningskommissionen samma observation. Med tanke på det starka kvinnounderskottet på landsbygden hade det, resonerade kommissionen, varit rimligast "om en exceptionellt stor del av de kvinnor, som dock finnas på landsbygden, varit gifta”. ${ }^{338}$ Så var dock inte fallet; även på landet fanns en hög andel yngre ogifta kvinnor. Befolkningskommissionen betecknade detta som "anmärkningsvärt" men gjorde ingen djupare analys av förhållandet. ${ }^{339}$

Även om de demografiska förhållandena säkert hade viss betydelse förmår de således inte helt förklara de uteblivna äktenskapen. Det rådde ingen fullständig brist på möjliga äktenskapspartner på landsbygden. Andra faktorer har sannolikt spelat en minst lika stor roll. Den franske historikern Georges Duby har pekat på ett starkt samband mellan giftermål och egendom. På grund av sin egendomsöverförande funktion är äktenskapet enligt honom intimt förbundet med samhällets "infrastrukturer" och skiftar betydelse "beroende på vilken roll arvet spelar i produktionsförhållandena [...] därför har den äktenskapliga institutionen till slut inget att bjuda slaven eller proletären, vilka, i avsaknad av fadersarv, naturligtvis bildar par men inte gifter sig". ${ }^{340}$ Dubys resonemang pekar mot förändrade egendomsförhållanden som en möjlig delförklaring till den sjunkande giftermålsfrekvensen. När ett traditionellt bondesamhälle allt mer övergick i ett modernt industrisamhälle blev tillgången till jordegendom mindre betydelsefull, vilket sannolikt medförde en minskad benägenhet att gifta sig. I en studie av samlevnadsmönster i 1800-talets Stockholm visar Margareta Matović tydliga skillnader mellan olika sociala skikt. Medan giftermål var grunden för samlevnad inom över- och medelklassen var det bland egendomslösa arbetare inte ovanligt 
med så kallad olegaliserad samlevnad. Matović menar att denna skillnad berodde på egendomsstrukturer. För dem som inte hade någon egendom att förvalta och föra vidare tjänade det inget funktionellt syfte att ingå äktenskap, särskilt som det innebar ekonomiska kostnader. ${ }^{341}$

Äktenskapets funktion för kontrahenterna är onekligen en viktig aspekt för att förstå varför olika samlevnadsmönster uppstod. Däremot förmår det inte förklara varför äktenskap uteblev också bland den jordägande befolkningen. Relationen mellan äktenskap och egendom var emellertid aktuell redan i samtiden, och den sjunkande giftermålsfrekvensen skylldes på föråldrade egendomsregler inom äktenskapet. Medan ogifta kvinnor alltsedan 1865 blev myndiga när de fyllde 25 år ställdes den gifta kvinnan under makens förmyndarskap och förlorade möjligheten till eget ekonomiskt handlande. Gifta kvinnor blev myndiga först i och med 1920 års giftermålsbalk. ${ }^{342}$ Maria Sjöberg tolkar uteblivna äktenskap som en social protest och understryker att de bar på en social sprängkraft som på sikt påverkade maktordningen mellan könen. Att kvinnor lät bli att gifta sig skapade dessutom spänningar mellan män med olika agendor. Fäder, makar och bröder hade inte alltid gemensamma intressen, Sjöberg betonar att "följderna av uteblivna giftermål berodde på vilken position de befann sig i" ${ }^{343}$

Resonemanget kan appliceras på de exempel som berörts tidigare. För den bror som övertog föräldragården var det inte optimalt att förbli ogift, eftersom han då gick miste om den egendom en hustru kunde ha medfört i äktenskapet. Däremot kunde det vara en fördel om systern förblev ogift, eftersom han då kunde bruka även hennes andel och eventuellt slapp att lösa ut henne ur gården. Att systrar inte sällan bodde kvar för att sköta sina bröders hushåll speglar det maktförhållandet. Men det finns också skäl att vända på frågan. Systerns position bör inte a priori tolkas som underordnad, särskilt inte efter 1890 då bröder inte längre kunde lösa ut sina systrars fastighetsarv mot deras vilja. Sjöbergs resonemang kan då omformuleras. Mäns uteblivna äktenskap hade också betydelse för kvinnor och berodde i lika grad på vilken position de befann sig i. För systern kunde en ogift bror erbjuda en möjlighet att stå 
kvar i ledningen för hushållet och kanske även som delägare. För en syster som inte gifte sig kunde en sådan lösning te sig attraktiv, åtminstone om alternativet var att flytta och ta ett lågkvalificerat arbete någon annanstans. Även själva jordbruket kunde gynnas av att arvingar förblev ogifta och stannade på gården. Eftersom de i regel hade vuxit upp på gården bör de ha haft bästa tänkbara kännedom om både hushållet och fastighetens förutsättningar, vilket medförde att transaktionskostnaderna inom jordbruket hölls nere. Att syskonen bands samman av ömsesidig lojalitet bör ytterligare ha förstärkt fördelarna med ett gemensamt brukande. Tidsaspekten var emellertid betydelsefull. Arvingarna kan inledningsvis ha haft andra ambitioner, som av en eller annan anledning inte blev verklighet. Att bruka gården gemensamt i något år är en sak, men om arrangemanget varade en längre tid kom det $i$ en annan dager. Det ömsesidiga beroendet mellan två eller tre ogifta syskon riskerade att få konserverande effekter som med tiden gjorde det allt svårare att bryta upp.

Äktenskapsförhållanden tycks följaktligen ha spelat en central roll för syskonhushållen. Uppgifterna i enkäterna möjliggör emellertid ingen djupare analys, och svar på centrala frågor som hur vanligt det var att syskonen förblev ogifta eller att samboendet så småningom upplöstes måste sökas i andra källor. Det gör jag i de två följande kapitlen. Hittills har jag dock enbart fokuserat på arvingarnas relationer, men generationsväxlingen var till syvende och sist en fråga som inbegrep relationen till föräldrarna. Vilken roll spelade de för att fler skulle överta gården gemensamt?

\section{Föräldrarnas betydelse}

En generationsväxling aktualiserar frågan vad som händer med de äldre som lämnar gårdsansvaret. Dog de, flyttade de eller drog de sig tillbaka i utbyte mot undantagsförmåner? I de tre enkäterna belystes föräldrarnas roll främst genom frågor om undantagsinstitutionen: hur vanlig var den, missbrukades den och vilka villkor uppställdes i kontrakten? Regleringen av undantagsförmåner för äldre jordbrukare har en lång historia och förutsättningarna har 
förändrats över tid. David Gaunt menar att undantagskontrakt under 1700-talet stegvis blev mer specificerade och allt oftare intecknades i fastigheten. Bakgrunden var att överenskommelsen inte enbart rörde daglig omvårdnad utan i allt större utsträckning också reglerade överföring av egendom mellan generationerna. ${ }^{344}$ Han betonar att kontrakten utformades för att gynna sammanhållningen inom familjen. Föräldrarna utkrävde vanligen inte alla tjänster och varor de enligt kontraktet hade rätt till, men om konflikter uppstod med efterträdaren eller denne dog var kontraktet en försäkring. ${ }^{345}$ En ytterligare aspekt, som Gaunt bara delvis berör, är att kontrakten innebar en säkerhet om gården gick ur släkten och de gamla jordbrukarna skulle försörjas av en ny ägare som de inte var släkt med. I takt med en växande jordmarknad var det inte en ovanlig händelse under 1800 -talet. ${ }^{346}$

Ett antal forskare har studerat villkoren för landsbygdens äldre under 1800-talet, men få vad gäller 1900-talet. ${ }^{347}$ Det hänger sannolikt ihop med utvecklingen till ett modernt välfärdssamhälle. Den första svenska pensionsreformen drevs igenom 1913 och under de följande decennierna byggdes pensionssystemet successivt ut. ${ }^{348}$ Den traditionella egendomsbaserade ålderdomsförsäkring som undantagskontrakt utgjort ersattes av ett generellt och offentligt finansierat välfärdssystem. Egendomens betydelse för äldres villkor minskade och av enkätsvaren framgår att de förändrade förutsättningarna fick praktiska följder. Åren 1907 och 1919 sades undantagsinstitutionen vara regel eller åtminstone mycket vanlig $\mathrm{i}$ drygt 60 procent av svaren, och i ett antal svar sades den förekomma men vara på nedgång. Denna tendens förstärktes kraftigt fram till 1935, då enbart runt 40 procent av svaren uppgav att undantagskontrakt var vanliga. På flera håll förekom de mer sällan eller hade rentav upphört. ${ }^{349}$ Några tydliga geografiska skillnader är svåra att belägga - förhållandena varierade ofta inom varje län - men grovt sett upprätthöll undantagsinstitutionen en stark ställning in på 1930-talet i Norrlandslänen, Västmanland, Uppland och Gotland.

Att undantagskontrakten minskade i omfattning runt sekelskiftet 1900 påtalas även av David Gaunt, som ser utvecklingen som ett tecken på att institutionen inte längre fungerade eftersom den 
innebar alltför stora konfliktytor mellan generationerna. Istället menar han att överlåtelsen i ökad utsträckning reglerades som en ren affärstransaktion, varpå föräldragenerationen levde på räntan av köpesumman. ${ }^{350}$ Senare forskare har dock ifrågasatt Gaunts bild av ökande spänningar mellan barn och föräldrar. ${ }^{351}$

I enkätmaterialet framskymtar en annan orsak till undantagskontraktens försvinnande: den nya folkpensionen. Kontrakten försvann "för att icke minska vederbörandes rätt till folkpension", hette det i ett svar från Västerbotten. ${ }^{352}$ En skånsk häradshövding förklarade förändringen med att de äldre ägarna blev berättigade till pensionstillägg när de frånträdde gården, vilket dock minskades "med ett undantagsförmånerna motsvarande värde, vilket brukar sättas relativt högt". ${ }^{353}$ De två försörjningssystemen ställdes därmed i ett direkt motsatsförhållande till varandra, vilket sannolikt påskyndade utvecklingen. Även andra ekonomiska incitament bidrog till att undantagskontrakten övergavs; exempelvis kunde de minska den nye ägarens möjligheter att belåna fastigheten. ${ }^{354}$

Undantagskontrakten var alltså på väg att ersättas av folkpensionering, men hur vanligt var det över huvud taget att föräldrarna drog sig tillbaka från jordbruket? I de två senare enkäterna ingick en fråga om huruvida egendom överfördes mellan generationerna i samband med dödsfall eller under föräldrarnas livstid. Visserligen framhölls i många svar att båda varianterna förekom parallellt, men totalt sett var det klart vanligare att gården överläts först i samband med dödsfall. ${ }^{355}$ Många äldre jordbrukare behöll kontrollen över gården livet ut, och i flera svar antyds att boet hölls intakt inte bara efter första förälderns död utan "till dess den siste av föräldrarna jämväl avlidit". ${ }^{356}$ Eftersom medellivslängden ökade under 1800-talet innebar det att det slutliga arvskiftet efter föräldrarna sköts upp till dess arvingarna själva var bortåt 40 eller 50 år gamla. ${ }^{357}$

Att föräldrar inte drog sig tillbaka utan ofta behöll gården fram till sin död torde ha bidragit till det minskande antalet undantagskontrakt. Men det ger också intressanta perspektiv på de långvariga gemensamhetsbruk som diskuterats tidigare i kapitlet. Ägandeförhållandena kännetecknades av en seghet som tycks ha 


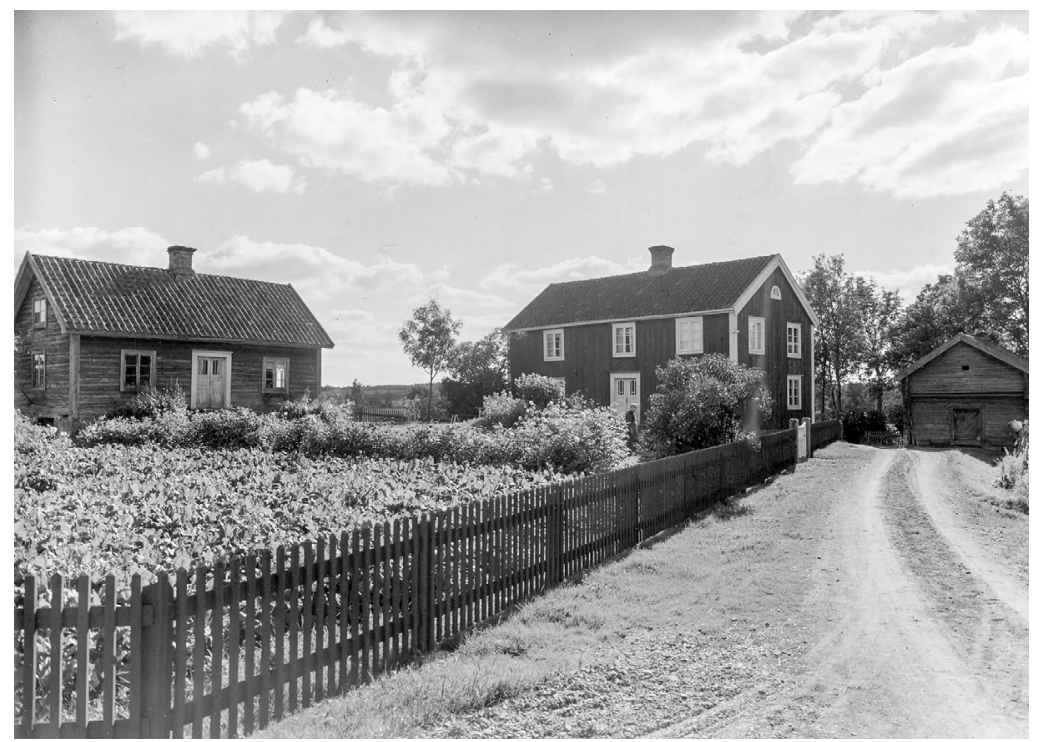

Om den äldre generationen drog sig tillbaka och höll sig med eget hushåll kunde de bo på övervåningen i boningshuset eller i ett separat bostadshus. Gårdsbebyggelse i Valåkra by i Högsby socken, Kalmar län. Mangårdsbyggnad i bildens mitt och undantagsstuga till vänster. Foto: Kalmar läns museum.

att göra med den ökade närvaron av vuxna barn. Enkäterna ger inga svar om hur vanligt det var att föräldrar ingick i sterbhusen, men här går att föra ett tentativt resonemang. En effekt av att föräldrarna inte lät ett relativt ungt barn ta över utan behöll både egendomen och ansvaret var att den ursprungliga familjekonstellationen inte splittrades genom en markerad och tydligt tidfäst generationsväxling. Visserligen kan gården informellt ha övertagits av ett av barnen, men det är sannolikt att hushållets strukturella stabilitet försvårade uppbrott och främjade kontinuitet. Många syskonjordbruk bör ha etablerats medan åtminstone en av föräldrarna ännu var i livet. Det riktar fokus mot hur relationerna mellan generationerna såg ut. 


\section{Konflikt eller sammanhållning?}

Att föräldrar i allt högre grad behöll äganderätten livet ut har uppmärksammats i tidigare forskning. För uppländska Estuna har Sofia Holmlund visat att ägobyten i samband med dödsfall förekom i mer än hälften av alla överlåtelser från föräldrar till barn under 180o-talets första hälft. Andelen sjönk något vid seklets mitt men växte kraftigt mot slutet av 1800-talet och under 1900-talets tre första decennier. Samtidigt steg föräldrarnas ålder vid överlåtelsen markant. Holmlund konstaterar att den ökande andelen transaktioner vid dödsfall inte berodde på demografiska faktorer utan istället måste tolkas som ett aktivt val från föräldrarnas sida. ${ }^{358}$ I sin undersökning av Dalboslätten finner Erik Hallberg ytterligare stöd för en sådan tolkning. Dödligheten sjönk och medellivslängden ökade, vilket fick till följd att äktenskapen varade längre. Dessa faktorer fick sammantaget en konserverande effekt på de jordbruk Hallberg undersöker. ${ }^{359}$ I en studie av ett antal jordbruk i Västergötland och Uppland betonar Iréne Flygare på liknande sätt att successionen under 1900-talet blev allt mer utsträckt i tid. Även om driftsledningen kunde överföras under faderns livstid behöll han inte sällan sin äganderätt livet ut. Flygare menar att en sådan utsträckt transitionsfas innebar flera fördelar, bland annat gav den utrymme för något barn att pröva på att driva gården på arrende innan den formella överlåtelsen genomfördes. ${ }^{360}$ Arrenderelationer mellan två generationer kan rentav ses som en modern och mer flexibel variant av de tidigare undantagskontrakten. ${ }^{361}$

Enkätmaterialets bild av en allt senare lösning av generationsskiftet överensstämmer således med andra forskares resultat. Som en förklaring till denna förändring framhålls ofta en mer markerad konflikt mellan generationerna. Nils Wohlin såg ett nytt maktförhållande där den yngre generationen satt med trumf på hand. Att frågan om gårdens framtid sköts upp till arvskiftet tolkade han som att den äldre generationen inte längre hade möjligheter att "göra sin vilja härutinnan gällande". ${ }^{362}$ Även senare forskare har menat att samhällsutvecklingen gynnade den yngre generationen. För ett område i Nordtyskland pekar Christine Fertig på att föräldrarnas ställning långsamt eroderade när arvingarna fick möjlighet att 
lämna gården för att skapa en bättre tillvaro på annat håll. Hon pekar dock på en omvänd följdverkan. Den yngre generationens ökade möjligheter tvingade många föräldrar att träda ifrån gårdarna tidigare för att alls kunna förmå något barn att stanna. ${ }^{363}$

Vanligare är dock att föräldrarnas maktposition betonas. Hallberg utgår i sin tolkning från föräldragenerationen och understryker de ökande svårigheterna för den yngre generationen att få tillgång till ett jordbruk. På sikt var föräldrarnas strategi att inte frånträda gården riskabel, den ledde till ökad rörlighet bland de yngre och i förlängningen hotade arbetskraftsbrist inom jordbruket. ${ }^{364}$ Holmlund ser föräldrarnas beslut att behålla äganderätten som en medveten strategi: de tvingades "bruka det medel som stod till buds - äganderätten till jorden - för att kunna uppnå sina målsättningar" ${ }^{365}$ Påståendet har dock dåligt stöd i Holmlunds egna resultat. Föräldrar hade även tidigare använt äganderätten som ett verktyg för att uppnå sina mål, om det vittnar undantagskontrakt och köpehandlingar. Som Holmlund själv påpekar hade föräldrarna störst möjlighet att utöva kontroll om de överlåt gården under sin livstid. ${ }^{366}$ Det var dock inte enbart mellan generationerna som det fanns en motsättning - Holmlund lyfter också fram de potentiella konflikterna inom den yngre generationen. Familjen som kollektiv aktör existerade enligt Holmlund knappast efter 1800-talets slut, istället blev generationsväxlingen i högre utsträckning ett resultat av ibland konkurrerande individuella strategier. ${ }^{367}$

Det är ovedersägligt att den yngre generationen hade helt andra valmöjligheter i början av 1900-talet jämfört med några decennier tidigare. Växande städer och tätorter innebar tillsammans med industrialiseringen nya sätt att leva och arbeta. Den industriella revolutionen nådde Sverige relativt sent, men när hjulen väl börjat snurra gick det fort och under en generation hann stora förändringar ske. Det kan ha lett till konflikter dels mellan och dels inom generationerna och häri ligger sannolikt en viktig förklaring till att många flyttade från landsbygden för att söka lyckan på annat håll. Alla familjerelationer behöver emellertid inte ha dominerats av konflikter. Även om enkätmaterialet inte håller för att dra alltför långtgående slutsatser är det svårt att förena konfliktperspektivet med allt fler 
långvariga sterbhus och samboende syskon. Om motsättningarna var stora, varför etablerades hushåll som snarast präglades av mer gemenskap än tidigare? I förhållandet mellan föräldrar och barn var det inte den ena av generationerna som satt på all makt och äganderätt. När en förälder avled innan generationsskiftet slutförts erhöll den efterlevande maken vanligen en del av egendomen som giftorätt. Många gånger måste därför samägandet under en period ha sträckt sig över generationsgränserna. En möjlig tolkning är att det fanns en betydande sammanhållning mellan dem som valde att stanna på landsbygden och föräldragården.

Jag underkänner inte konfliktperspektivets betydelse; motsättningar existerade men parallellt med sammanhållning. I en del fall skärptes konflikter och arvingarna lämnade hembygden, i andra drogs familjemedlemmarna snarast närmare varandra. Med tanke på att många syskonhushåll tycks ha etablerats medan föräldrarna ännu var i livet är det inte orimligt att se dem som ett uttryck för en gemensam familjestrategi snarare än syskonens individuella strategiska överväganden. Det behöver inte innebära att alla i hushållet strävade efter att gården skulle förbli intakt och det finns ingen anledning att betrakta samboendet som en rosenskimrande familjeidyll. Alla arvingar stannade inte på gården och även bland de kvarboende kunde det finnas olösta konflikter. I många fall var sannolikt sammanhållningen snarast ett utslag av pliktkänsla - mot gården, familjen eller föräldrarna.

\section{Tre resultat och en slutsats}

I detta kapitel har jag belyst arvsförhållandenas utveckling under 1900-talets första hälft med utgångspunkt i tre nationella enkäter. Resultaten kan summeras i tre punkter.

För det första bär materialet tydlig vittnesbörd om en ökad närvaro av vuxna syskon på gårdarna. Ett enarvingesystem dominerade men det går att skönja konturerna av ett framväxande flerarvingesystem. Det var emellertid inte fråga om något regelrätt realarv eftersom gårdarna inte delades i praktiken. De två klassiska arvsprinciperna förmår inte fånga de två centrala dragen i de 
långvariga gemensamhetsbruken: gården övertogs av flera arvingar men hölls ihop. Gemensamhetsbruken nämns något oftare i svar från västra Sverige men under 1920- och 1930-talen var de allmänt förekommande i hela landet. Någon regional sedvänja tycks det således inte vara fråga om. Även när en arvinge ensam övertog jorden var det inte ovanligt att syskon stannade kvar på föräldragården, ibland under avsevärd tid. Det går inte att fastställa hur vanligt detta varit, men det tycks ha förekommit på de flesta håll i landet.

För det andra speglar materialet ett förändrat äktenskapsmönster. I enkätsvaren är "ogift" ett nyckelbegrepp. I flera fall förefaller det närmast ha varit en förutsättning för syskonjordbrukets uppkomst att de inblandade var ogifta, även om det är oklart hur det kausala sambandet såg ut mellan att inte gifta sig och att bo kvar på föräldragården tillsammans med ett eller flera syskon. Det fanns en tydlig skillnad i könens egendomsrättsliga ställning: det var systrar som stannade hos bröder, inte tvärtom. Systerns position tycks ha varit avhängig av att brodern förblev ogift, varför samboendet syskonen emellan kan ha legat som en hämsko på äktenskapsbildningen.

För det tredje antog generationsväxlingen nya former. Föräldragenerationen tycks generellt ha blivit allt mer ovillig att släppa ifrån sig kontrollen och i flera svar framgår att jordbruk drevs som sterbhus tills båda föräldrarna gått bort, vilket många gånger måste ha inneburit att arvingarna själva var relativt gamla när det egentliga arvskiftet förrättades. I en del fall hade arvingarna för länge sedan lämnat boet, men fördröjningen kan också ha varit en anledning till att arvingarna stannade kvar tillsammans på föräldragården.

Läggs resultaten från detta och föregående kapitel samman kan en viktig slutsats dras. De samägda syskonenheter som började uppmärksammas under 1950-talet var inte primärt en effekt av strukturrationaliseringen utan en företeelse som var känd redan vid seklets början och några decennier senare förekom över hela landet. Enkätmaterialet ger underlag för att tolka dessa nya familjeenheter som en kollektiv handling, där en gemensam familjestrategi sattes före konkurrerande individuella strategier. Det är dock en tolkning som måste belysas från flera håll. Den bild som jag har skisserat i detta och föregående kapitel är baserad på förhållandevis 
grova beskrivande omdömen och väcker en rad nya frågor. När syskonjordbruken började dyka upp är osäkert, liksom hur de har utvecklats över tid. Framför allt saknas svar på mer konkreta frågor: Vilka syskon rörde det sig om? I hur stor utsträckning bestod hushållen av både systrar och bröder? Hur vanligt var det att syskonen förblev ogifta? För att kunna besvara dessa frågor är det nödvändigt att byta perspektiv. I nästa kapitel riktar jag fokus mot enskilda och konkreta exempel. 